\title{
Müzik Analizinde Schenker Yaklaşımı
}

\section{Schenker Approach in Music Analysis}

\author{
Ebru BULUR ${ }^{1}[0$
}

DOI: 10.26650/CONS2019-0004

'Istanbul Üniversitesi Devlet Konservatuvarı, İstanbul, Türkiye

ORCID: E.B. 0000-0003-0240-1935

Sorumlu yazar/Corresponding author: Ebru Bulur,

İstanbul Üniversitesi Devlet Konservatuvarı, İstanbul, Türkiye

E-posta/E-mail: ebru.bulur@istanbul.edu.tr

Başvuru/Submitted: 13.03.2019

Revizyon Talebi/Revision Requested: 10.06.2019

Son Revizyon/Last Revision Received: 16.06.2019

Kabul/Accepted: 21.06 .2019

Online Yayın/Published Online: 28.06.2019

Atıf/Citation: Bulur, E. (2019). Müzik analizinde Schenker yaklaşımı. Konservatoryum -

Conservatorium, 6(1), 21-46.

https://doi.org/10.26650/CONS2019-0004

\section{öz}

20. yüzyıl, bestecileri geleneksel kurallardan vazgeçiren bir yüzyıl olmuştur. Tonal düzenin getirdiği kurallara karşı çıkan pek çok akım, yeni denemelere girişen besteciler, çağa damgasını vurmuştur. Viyanalı müzik kuramcısı Heinrich Schenker'in (1868-1935) bu kadar yeni akımın içinde tonaliteye sadık kalan ve tüm analizini tonik akoru ve onun açılımları üzerine kurgulaması, ister istemez oldukça dikkat çekicidir. Bu makale, Schenker analizini, genel başlıklar altında inceleme amacıyla gerçekleştirilmiştir. Schenker'in kariyeri boyunca geliştirdiği fikirler ana hatlarıyla anlatılmaya çalışılmış, Schenker analizi genel kavramlar, armonik yapı, melodik kavramlar ve grafik notasyon, başlıkları altında örneklerle incelenmiştir. İlgili kaynaklara, bilimsel araştırmalara, analizlere, literatür taraması yoluyla ulaşılmıştır. Eser analizi yapılmamış, tekniği anlatabilmek için literatürden seçilmiş örnekler kullanılmıştır. 20. yüzyılda ortaya çıkan yeni analiz yöntemlerinin birkaçına genel olarak değinilmiş, ancak tüm bu yöntemlerin başlı başına başka bir araştırma konusu olması nedeniyle detaylandırılmamıştır. Schenker analizi hakkında Türkçe kaynakların sınırlı sayıda olması nedeniyle bu makale literatür eksikliğini bir nebze gidermeyi ve Schenker analizi hakkında genel bir fikir vermeyi amaçlamaktadır.

Anahtar Kelimeler: Schenker, Müzik Analizi, Tonalite

\section{ABSTRACT}

20th century is a period when composers abandoned traditional norms. Various trends defying norms imposed by tonal harmony and composers who experimented with new forms left their imprint in last century. It is striking that Heinrich Schenker (1868-1935), Viennese music theorist, remained faithful to tonality, structured his analysis on tonic triad and derivations despite new trends. Schenker in this theory explained basic structure of musical pieces and hierarchical relations through technique of prolongation. This article aims to evaluate the Schenkerian analysis, under general headings. Hereby, ideas that Schenker developed over lifetime are provided in general; Schenkerian analysis is observed with examples in general section terms, harmonic structure, melodic notions, graphic notation. Analysis of work is avoided and to describe the technique, selection of samples, chosen from literature is used. Related resources are obtained through literature survey of relevant academic researches and analyses. Some new analysis techniques, that emerged in 20th century are briefly mentioned in essay but not examined in detail since each of them is topic of separate research. Due to limited number of Turkish sources on Schenker's analysis, this article aims to remedy this deficiency in literature and provide general information on Schenker analysis.

Keywords: Schenker, Musical Analysis, Tonality 


\section{EXTENDED ABSTRACT}

Heinrich Schenker, (1868-1935) is a Viennese music theorist. The Schenker analysis is a method of analyzing tonal music using Heinrich Schenker's theory and analytical techniques. The preliminary conceptual framework for the Schenker analysis first appeared in the analyses that are published in Der Tonwillede (1921-24), however, ideas about fundamental content is not pronounced until the publication of Der Freie Satz (1935). The core of Schenker's theory can be found in the three volumes of Neue musikalische Theorien und Phantasien: Harmonielehre (1906), Kontrapunkt I-II (1910, 1922), and Der Freie Satz (1935). Schenker's last work, Der Freie Satz (Free Composition) is published shortly after the death of the author in 1935.

The principles of this theory that Schenker developed for the study European music of the 18th and 19th centuries (late baroque - early romanticist) are initially implemented by his pupils and himself. It reached a wider audience owing to the school, which Oswald Jonas and Felix Salzer founded in the USA. Especially after the translation of Der Freie Satz into English in 1979, this theory became a principal analytical method used by many music analysts by the 1980s. By the mid-1980s, two methods of musical analysis approaches became mainstream, one for analyzing tonal music and other for atonal music. One of these methods is 'the Schenkerian' analysis whereas the other is 'the pitch class set' analysis. As a result, a clear-cut separation between tonal and atonal analysis is set.

In the multilayered structure of his analysis, Schenker aimed to show the basic structure of a musical work through the technique of prolongation and the hierarchical relations. He used a special symbolic music notation in his system of analysis. Schenker with the analysis he made, synchronically synthesized many musical parameters with contrapuntal and harmonic component structure and explained about analyzing in a minimal level. The Schenkerian analysis, which refers to a kind of systematic analysis today continued to grow through the works of the students of Schenker after his death and inspired a variety of other analytical methods in later years.

In this article, general information about the developments in music analysis in the 20th-century, some analysis methods and Schenker analysis will be given. While there are many works on the Schenker analysis in the relevant international literature, similar studies in Turkish are quite limited in number. 
In the first section of the article, the general definition of analysis and some of the techniques of 20th-century analysis are discussed. Amongst 20th-century analysis techniques, Schenker analysis is chosen and examined in general. In the beginning, general concepts of Schenker analysis is introduced. Familiarity with key terms of the Schenker analysis is essential for understanding the theory itself. In Schenker analysis which is a formation of prolongation technique and layered structure, various melodic components used from background to foreground of a musical piece and usage of these components is briefly explained. Also, the peculiar chord system he developed, harmonic structure and the use of harmonic structure with melodic components are briefly mentioned. The graphic notation he applied is elaborated through concrete examples. Rather than attempting to analyze the musical piece, here it is limited to describe the Schenkerian analysis and classical analysis through a selection of examples from the relevant literature.

In conclusion, it is underlined that there are differences between the Schenkerian analysis and traditional analyses in terms of gradation and while Schenkerian analysis appears to be difficult to understand for the beginners, still the Schenkerian analysis offers a convenient methodology for analyzing tonal pieces. Analysis means an interpretation and no particular method or form of analysis should be accepted superior to others. 


\section{Müzik Analizine Giriş}

Analizin en basit tanımı çözümlemedir. Analiz yapabilmek için genellikle parçanın nispeten daha basit ve daha küçük kısımlara bölünmesi ve bu kısımların birbirleriyle olan fonksiyonel ilişkilerinin incelenmesi gerekir. "Analiz, bir eserin çeşitli kısımlara ayrılmasıdır. Sentez, çeşitli kısımları tek bir prensipten büyüyen bir eserin yeniden birleştirilmesidir" (Katz, 1935, s. 312).

Analiz, müzikal yapının göreceli olarak daha basit kurucu bileşenlere çözümlenmesi, bu bileşenlerin birlikte yorumlanması ve bu bileşenlere ait fonksiyonların incelenmesidir (Sadie, 2001, s. 526).

Analiz, müzikal eserlerin işlevsel tutarlılığını ayırt etmeyi ve göstermeyi amaçlamaktadır. Herhangi bir müzik parçasını, hiçbiri bir başkasını tamamen kopyalamayan birçok şekilde analiz etmek mümkündür. Bu çeşitlilik kaçınılmazdır çünkü analiz bir yorumdur. Kuramsal bilgiler eser hakkında bilgi edinmeyi, analiz ise bu bilgileri uygulama olanağı tanır. Analiz ile bir müzik eseri çözümlenir, yapısı anlaşılır, analiz yöntemleri farklı da olsa sonuç doğru ya da yanlış olarak değerlendirilmez.

Müzikal analiz ifadesi çok çeşitli aktiviteleri kapsar. Müziğin doğası, müziğin insan yaşamındaki rolü ve müzikle ilgili insanın fikri ile ilgili temel olarak farklı görüşler vardır. $\mathrm{Bu}$ görüş farklılıkları, analizin kendi sınırları içinde tanımlanmasını zorlaştırır. Müzikal analizin, bilimsel bir yaklaşım ve yöntem olarak görülmesi 19. yüzyıl sonlarına doğru başlanmıştır. Bu süreç içerisinde de müzikal analiz, çeşitli evrelerden geçmiştir (Sadie, 2001).

Analiz tanımını ilk yapan Joachim Burmeister (1566-1629) olarak bilinir. Burmeister, eserin modunun, eserin ne tür bir kontrpuanla yazıldığının, cümlelerinin ve periodlarının belirlenmesi ile analiz edilebileceğini söylemiştir (Sadie, 2001, s. 530). Ancak o dönemdeki cümle ve period tanımı günümüzde anladığımız anlamda kullanılmamaktadır.

Bir eser analiz edilirken, her yönüyle dönem stilini de dikkate almak gerekir. Bu açıdan bakıldığında müzik tarihi bilgisi stiller arasındaki ilişkiyi saptamak, eserlerin dönemsel özelliklerini bilmek ve analizi buna göre şekillendirmek için önemlidir. Analiz için nesnel bir bakış açısına sahip olmak gereklidir. Bu niteliği doğru bilgi ve birikim ile harmanlayabilmek iyi bir analizi getirir.

Müzikal analizin ana konusu karşılaştırmadır. Karşılaştırma yaparak, yapısal öğeler be- 
lirlenir ve bu öğelerin fonksiyonları bulunur. Karşılaştırma, her türlü müzikal analiz için s1k uygulanan bir yöntemdir.

19. yüzyıldan günümüze kadar kullanılan birçok analiz yöntemi olmasına rağmen, en yaygın olarak kullanılmış analiz yöntemleri arasında armonik analiz, form analizi, Schenker analizi ve perde sınıfi analizi sayılabilir.

\section{Analiz Yöntemlerine Genel Bakış}

20. yüzyıl birçok tekniğin bulunduğu ve bir arada sunulduğu bir dönemdir. Müzik analizi alanında da pek çok yeni yöntem ortaya çıkmış, gelişmeye devam etmiştir. Kuramcılar müzik analizini kullanılan yönteme göre çeşitli başlıklarla sınıflandırmışlardır. Hermann Erpf (1891-1969) müzik analizini yapısal analiz (constructional analysis), psikolojik analiz (psychological analysis) ve ifade analizi (analysis of expression) olarak üç temel başlık altında toplar. Buna karşın Leonard B. Meyer (1918-2007) müzik analizini formal analiz (formal analysis), kinetik-sözdizimsel (kinetic-syntactic analysis) ve gönderimsel analiz (referential analysis) şeklinde sınıflandırır. Her iki sınıflandırma tam olarak birbirine karşılık gelmese de bu sınıflandırmaların birbirine eşit olduğu düşünülebilir (Sadie, 2001, s. 528).

Carl Dahlhaus ise (1928-1989) müzik analizini formal analiz (formal), hareket analizi (energetic), algısal analiz (Gestalt) ve yorumlama analizi (hermeneutics) olmak üzere dört gruba ayırmıştır. Diğerlerinden farklı olarak algısal analiz, müziği oluşturan yapının birbiriyle bağlantılı olduğu bütünsellik fikri üzerine kuruludur (Sadie, 2001, s. 528).

1950'li yıllarda motifsel gelişme ve analize ilişkin yeni yaklaşımlar ortaya çıkmıştır. Rudolph Réti (1885 -1957) bu gelişmeyle ilgili "Müzikteki Tematik Süreç" (1951) ve "Tonalite, Atonalite, Pantonalite" (1958) adında iki kitap yazmıştır. Réti ilk kitabında Schoenberg'in motif genişlemesi, bölünmesi ve sınırlandırılması ile ilgili görüşlerini temel alır. Bir eserin tüm tematik materyallerini, ortak unsurlarına indirgeyerek, motifin içinden "hücre"yi üretir. Bunlar iki veya üç aralık içeren ve ritmik olmayan küçük ölçekli melodik hatlardır. Reti'nin yönteminin kaynağı ritmik olarak tanımlanmış "motifler" yerine küçük "perde hücreleri” dir. Hücre, transpoze edilebilir ve çevrilebilir. Réti, geniş çaplı bir çalışmanın her bölümünde "tematik bir model” olarak yinelenen bu hücrelerin, bir kalıp olarak kendine has tekrarlar oluşturduğunu tespit etmiş ve bir eseri "birkaç motifin etrafında müzikal bir doğaçlama" olarak görmüştür. 
Reti, "motifsel analiz" terimini beğenmeyerek, büyük ölçekli formlar için "tematik analiz” terimini kullanmıştır (Cook, 1987, s. 106). Ancak yöntem temanın yatay boyuttaki gelişimi ile ilgili olduğundan armonik yapıyı ikinci plana atar.
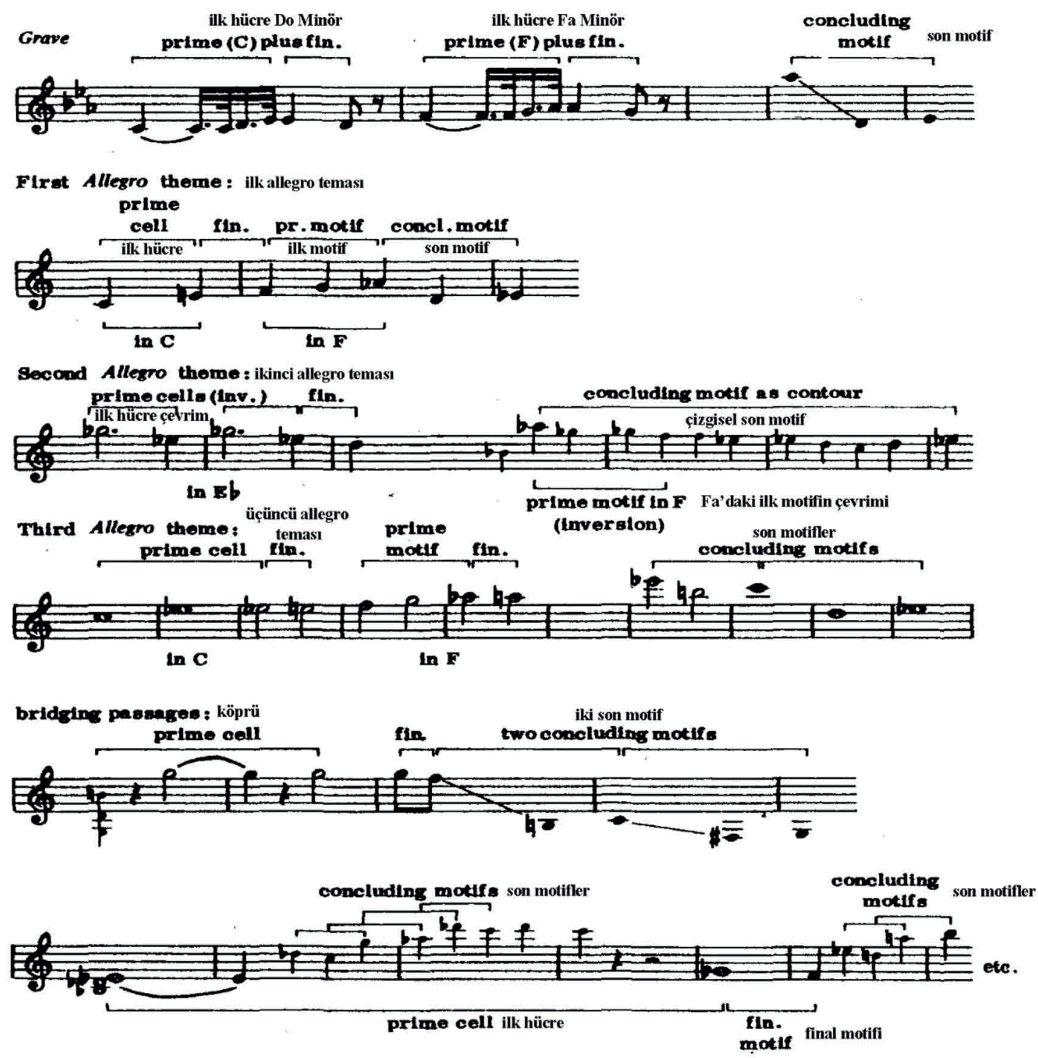

Şekil 1: Reti'nin tematik kalıpları, Beethoven, "Pathetique” Sonat (Cook, 1987, s. 104)

Aynı dönemlerde Hans Keller (1919 -1985), “işlevsel analiz”in ilkelerini öne sürmüştür. Keller, müzikal düşüncenin iki boyutlu olduğunu söylemiştir. Bunlar “Ön plan” ve "Arka plan"dır. Keller'e göre bir eser farklılıklar içinde birlikteliğe sahiptir. Bu bağlamda Keller bir müzik eserinde çeşitlilik içinde birlik kavramını aramaktadır. İlk yapılması gereken bu birlikteliği oluşturan temel düşüncenin yani hücrenin saptanması, yeniden üretilmesi ve bu döngünün tekrar edilmesidir. Analiz yaparken eserin içine yayılmış olan bu temel fikri bulmaya çalışmak önemlidir.

“Perde sınıfı analizi” 20. yüzyılın ilk yarısındaki atonal müziği analiz etmek için 1980’lerin ortalarında geliştirilmiş bir analiz yöntemidir. Kökeni, Georg Cantor'un (1845-1918) 
1874 ve 1897 yılları arasındaki çalışması olan matematiksel küme teorisine dayanır. Küme teorisinin müziğe uygulanması 1925 y1lında J. M. Hauer (1883 -1959) ile gerçekleşmiştir. Allen Forte (1926 -2014) ise geliştirmiştir. Perde sınıfı analizinin amacı, atonal müziğin yapısı hakkında fikir vermektir. Çünkü bu tür müziklerde tonik, tonik akoru ve tonaliteye ait çok fazla bağlayıcı bir öğe olmadığından, müziği anlamaya ve yorumlamaya yönelik bir yöntem gereklidir. Perde sınıfı analizinin çıkış noktası, tonal olmayan müziği anlamak için bir "dil" oluşturmaktır. Forte, bu konuda "Herhangi bir atonal kompozisyonun açıklanması ve yorumlanması için bir çerçeve oluşturur" demiştir (Cook, 1987, s.124). Forte, anarmonik notaları göz ardı ederek, bir oktavı 12 eşit parçaya bölmüştür. Bir oktav içindeki on iki perdenin her birinin ancak tek bir adı olabilir. Bu anlamda do, si diyez, re çift bemol notalarının hepsi aynı perdeyi tanımlar. Farklı oktavlardaki ses perdelerini de temsil eden bu 12 sesin oluşturduğu küme "perde sınıfı"nı oluşturur.

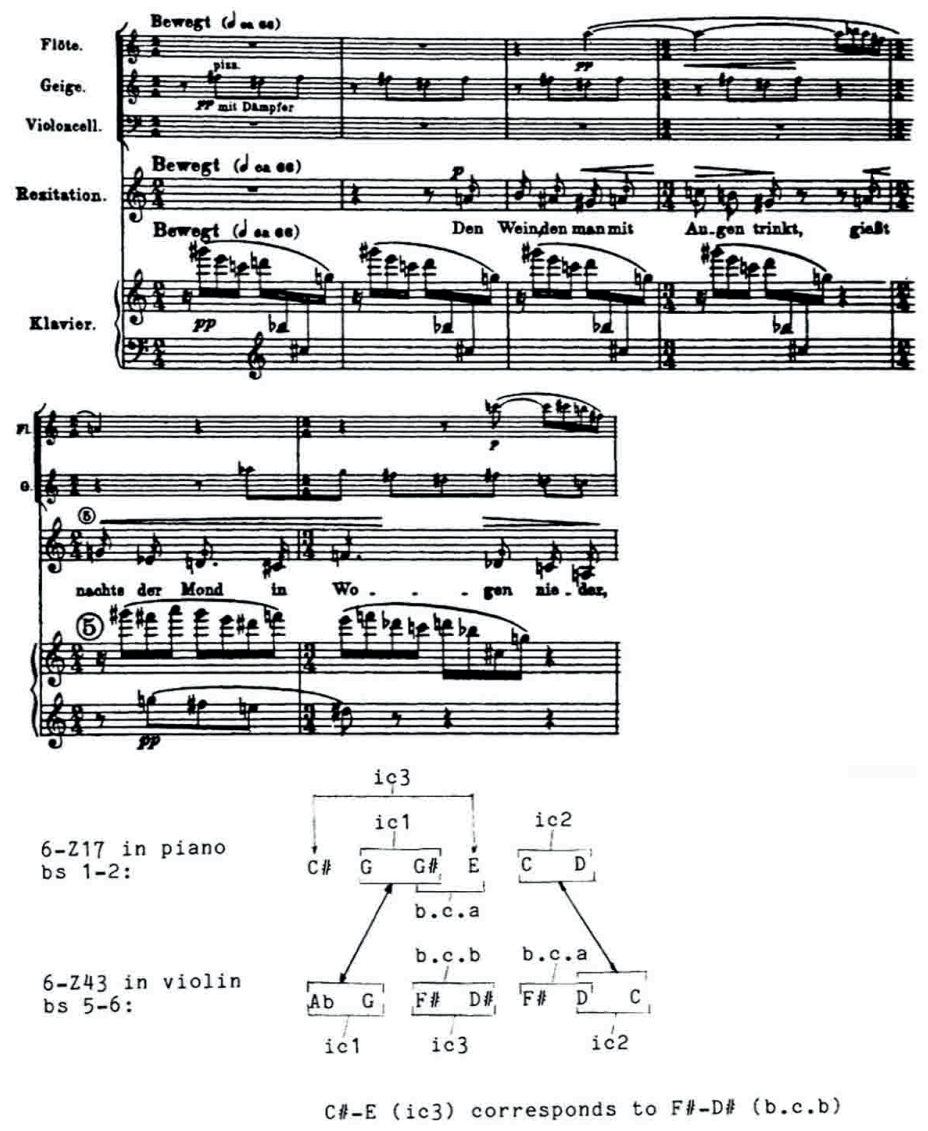

Şekil 2: Schoenberg, Pierrot Lunaire (Forte, 1985, s. 55) 
Üretken Tonal Müzik Teorisi, (A Generative Theory of Tonal Music) besteci Fred Lerdahl ve dilbilimci Rey Jackendoff'un beraberce geliştirdiği, Heinrich Schenker'in müzik analizi ve Noam Chomsky'nin dilbilim kuramı üzerine kurulmuş, müziğe dinleyici gözüyle bakarak müziğin nasıl kavrandığına yönelik uygulanan bir analiz yöntemidir. Lerdahl ve Jackendoff, bir müzik yapıtının belirli yönlerini yansıtmak, ortaya çıkarmak, incelemek için bir model oluşturmayı amaçlar. Lerdahl ve Jackendoff çalışmalarında, Schenker analizini temel alan kuramlarını Gestalt psikolojisi ilkelerine dayandırırlar. Lerdahl ve Jackendoff, müzik kuramı ile dilbilim arasındaki metodolojide önemli farklılıklar olduğunu kabul ederler, ancak dilbilimsel modellerin çoğunu da benimserler. Lerdahl ve Jackendoff'un kuramı, dört temele dayanır:

Gruplama yapıs1 (grouping structure), ölçü yapıs1 (metrical structure), zaman aralığ1 azalmas1 (time-span reduction), uzun süreli azalma (prolongational reduction) (Sadie, 2001, s. 565)

"Hepsi bir parçanın yapısal tanımına giren dört bileşen önermekteyiz. Genel olarak, gruplama yapısının, parçanın motifleri, cümleleri, kesitleri gibi hiyerarşik bölünmesini ifade ettiğini söyleyebiliriz. Ölçü yapısı, parçanın hiyerarşik düzeydeki güçlü ve zaylf zamanlarının düzenli bir şekilde değişmesi ile ilgili olduğunu ifade eder. Zaman aralı̆̆ azalmasl, perdenin gruplama ve metrik yapıdaki konumlarına göre "yapısal önem” hiyerarşisini saptar. Uzun süreli azalma, perdenin gerginliğini ve rahatlamasını, sürekliliğini ve bağlantılarını ifade eden bir hiyerarşik anlam taşır." (Lerdahl ve Jackendoff, 1983, s. 8-9) 

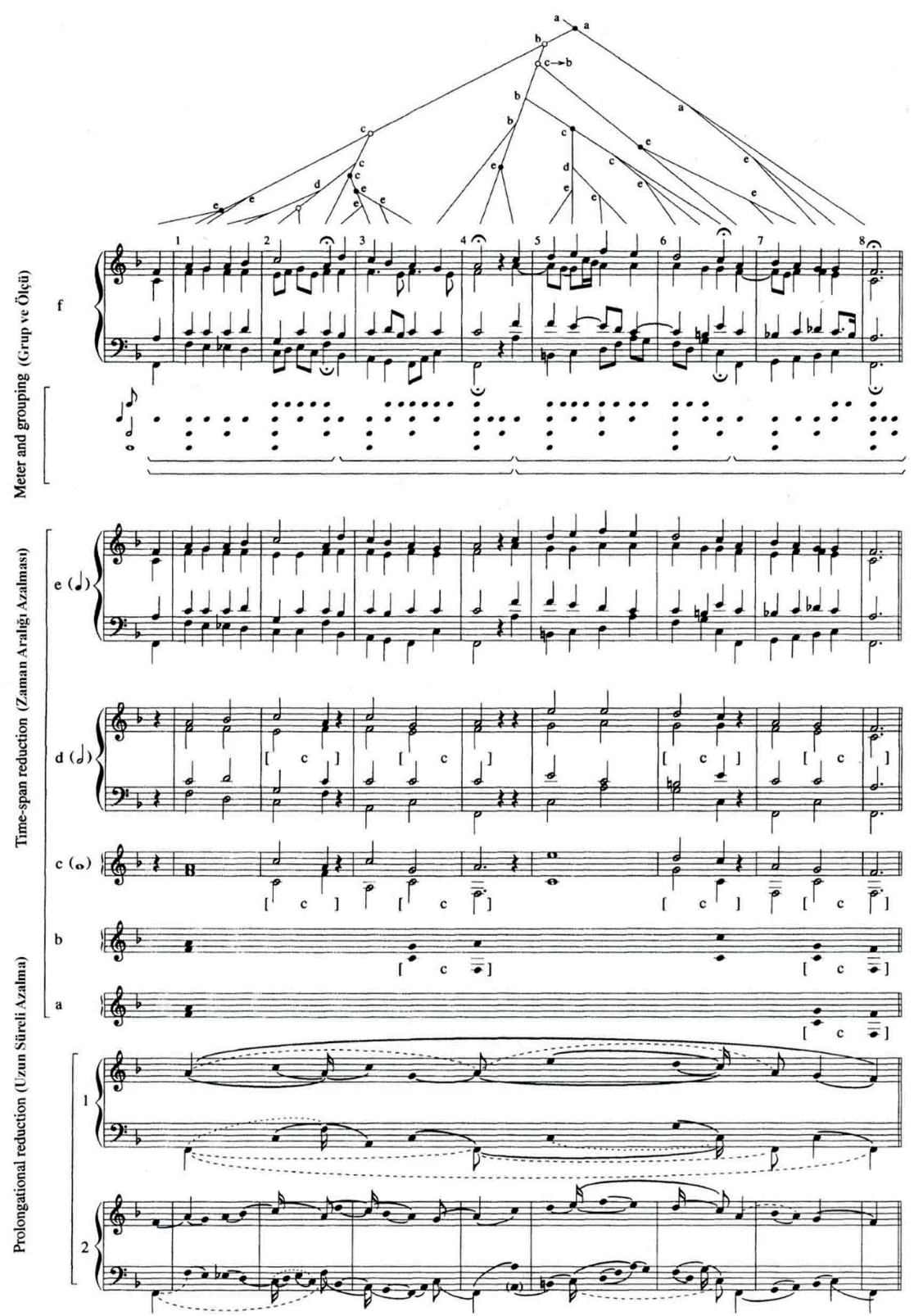

Şekil 3: Lerdahl ve Jackendoff, üretken tonal müzik teorisi grafiği (Hansen, 2010, s. 36)

Şeklin tepesindeki ağaç yapısı, dallanma yapısına göre hiyerarşik seviyelere ayrılabilir. Analizdeki ağacın yaprakları, bir müzik parçasının partisyonunda bulunan notaları temsil ederken, ağacın dalları da bu notaların detaylandırılmasını temsil eder. 
20. yüzyılda gelişen analiz yöntemleri, bu alana zenginlik katarken, Schenker analizi etkisini uzun yıllar sürdürmüştür. Örneğin tematik analiz, eserlerde bulunan küçük hücre kalıplarından bahsederken Schenker analizi, tonal sürekliliği korumaya yönelik bir analiz sunmuştur. Geleneksel kuramcılar, müzik tarzlarının çeşitli dönemlere göre farklılık gösterdiğini savunurken Schenker, tüm büyük bestecilerin müziğindeki yaratıda temel ilkelerin aynı olduğunu anlatır. Dolayısıyla bir analiz, eseri netleştirmeli, aydınlatmalı ve kolay anlaşılır kılmalıdır. Schenker'in müziğe devrim niteliğindeki yaklaşımı, bir eserin yorumlanması ve performansı üzerinde de önemli bir etkiye sahip olacağından bu analiz yaklaşımının öğrenilmesi önemli katkılar sağlayacaktır.

\section{Schenker Analizi: Genel Kavramlar}

Schenker'in tonalite anlayışına göre oluşturduğu bu analiz yöntemi, müziği sadeleştirerek genel yapıyı minimal düzeyde analiz etmeyi amaçlar. Schenker, genel yapıyı oluşturan müzikal öğelerin, eserin içinde hangi amaçla ve nasıl kullanıldığı sorusuna cevap arar. Tonal müzikleri analiz edebilmek için uygulanan bu yöntem, atonal müzik anlayış1na göre kullanışlı değildir. Öncelikle tonal eserleri analiz etmek için oluşturulmuş bir yöntem olduğundan tonalite kelimesinin anlamını bilmek de önemlidir.

Tonalite kelimesinin "ton" kelimesinden türemiştir ve bu anlamda bir ses perdesini ya da sesi simgelemektedir (Say, 2002 s. 522).

Tonalite, ilk olarak 1810 'da Choron (1771-1834) tarafindan, dominant ve alt dominant fonksiyonlarının toniğin üzerindeki ve altındaki yerini tanımlamak ve modern müziğin armonik yapısını önceki müzikten ayırt etmek için kullanılan bir terimdir. Bununla birlikte mümkün olan en geniş anlamıla, perde olgusunun sistematik düzenlemelerini ve bunlar arasındaki ilişkileri ifade eder (Sadie, 2001 s. 583).

Dallin geleneksel tonalite anlayışını şöyle ifade eder:

- Materyalin temel kaynağı olarak sabit bir kalıpta (majör-minör dizi) bulunan sınırlı sayıda notanın kullanılması,

- Parça içindeki diğer notaların (armoniye yabancı notalar) yardımcı notalar olarak yapıya dahil edilmesi,

- Belirli fonksiyonların belli başlı armonik unsurlar çerçevesinde adlandırılması (I. derecenin tonik, V. derecenin dominant olmas1) (Dallin, 1964, s.115). 
Ancak Schenker'e göre tonalite hem doğal hem de sonsuz sayıda kurala tabiidir. Tonalite en doğal tonik akorunun içinde yer alır. Schenker analizi, Batı müziğinin genel perde yapısını açıklamak için kullanılan bir yaklaşımdır. Kuramcılar, Schenker'in fikirlerinin bazı temel şartlara uyması gerektiği sonucuna varmışlardır. Buna göre:

- Diyatonik dizi birincil dizidir ve kromatik sesler her zaman buna göre ikincildir.

- Armoni tonaldir yedili akorlarla da yapılsa beşli akorlar sabit unsurlardır.

- Beşli aralıklar armonide yer alan en önemli aralık sınıfıdır (Schenker, 1979).

Bununla birlikte sesleri tek olarak değil, temel sesin armoniklerinden oluşan bir bütün olarak düşünmek gerekir. Herhangi bir temel sesin ilk beş armoniği majör akoru oluşturur.

Katz, tonaliteyi tonik akorunun dönüşümü olarak tanımlamıştır. (Katz, 1935, s. 313).

Bu tanım Schenker analizinin özüdür. Schenker'in tonal eserler için tonik akorunun dönüşümü ile ilgili fikri kariyerinin son 30 yılında oluşmuştur.

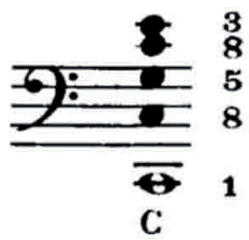

Şekil 4: Armoniklerin ilk beş notası (Schenker, 1979, Şekil 2)

Tonik akorunun inici yatay hali “temel çizgi”yi (Urlinie), kırık akor halinde kullanımı ise "bas arpeji”ni (Bassbrechung) oluşturur. Temel çizgi tamamen melodiktir ve tonik akorunun üçlüsü, beşlisi, sekizlisinden başlayarak toniğe doğru inici melodik bir hat oluşturur. Bas arpeji ise temel bir arpejden oluşur. Schenker diyatoniyi temel çizginin içeriği olarak tanımlamıştır. Bitişik olarak inen seslerin tonik akoru sesleri dışında kalanları da melodik akış içinde geçit notaları olarak tanımlanır. "Diyatonide ezgisel temel, belirgin bir melodik akış olarak karakterize edilir. Buna karşın ön planda yer alan tonalite, en küçüğünden en geniş kapsamlısına kadar tüm sesler ve müzik formları da dahil olmak üzere tüm oluşumların toplamını temsil etmektedir”' (Schenker, 1979, s. 5).

Temel çizgi ve bas arpeji, Schenker'in Ursatz adını verdiği “temel yapı”yı oluşturur. Temel yapı, parçada bir tonik akorunun armonik ve kontrapuntal açılımıdır da denilebilir. 


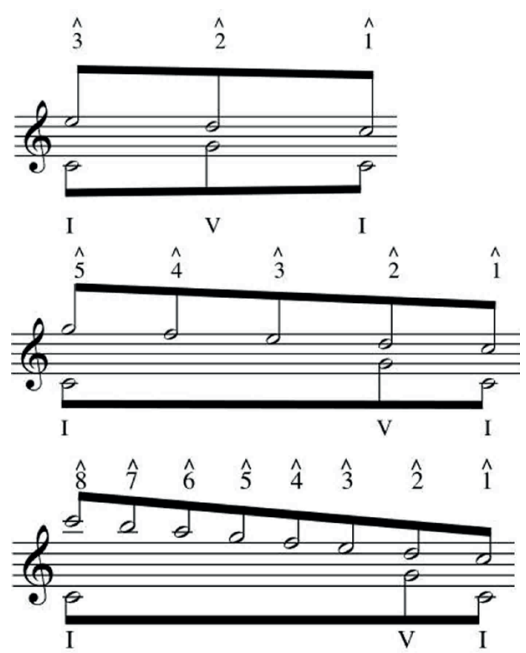

Şekil 5: Ursatz'ın üç formu (Drabkin, 2002, s.819)

Schenker, müziği katmanların (Schicht) üst üste gelmesi olarak görmüştür. Bu katmanlar “ön plan” (Vordergrund), “orta plan” (Mittelgrund) ve "arka plan” (Hintergrund) olmak üzere üçe ayrılır. Müziğin yüzeyi ön plan, en derin tabakası arka plan ve aradaki ayrıntıların katmanı orta plandır. Orta planda ön planın hemen ötesinde kalan yapısal malzemeler bulunur. En çabuk algılanabilen unsurlar ön plandadır. Temel çizgi Schenker'in analiz sistemine göre ön planda bulunur. Bas arpeji ise arka plandadır. Schenker analizi ile ilgili en önemli kavramlardan biri olan temel yapı, Schenker'in iyi bestelenmiş her müzik parçasında bulunduğunu iddia ettiği arka planda yer alır.

Schenker, müziği arka plandan ön plana kadar olan detaylandırılmış katmanların analizi olarak değerlendirir. Her katman, farklı anlamlarda kullanımıyla ifade edilir. Schenker, "müzikal tutarlılığa ancak arka plandaki temel yapı ve orta ve ön plandaki dönüşümler yoluyla ulaş1labileceğini” söylemiştir (Schenker, 1979, s. 6).

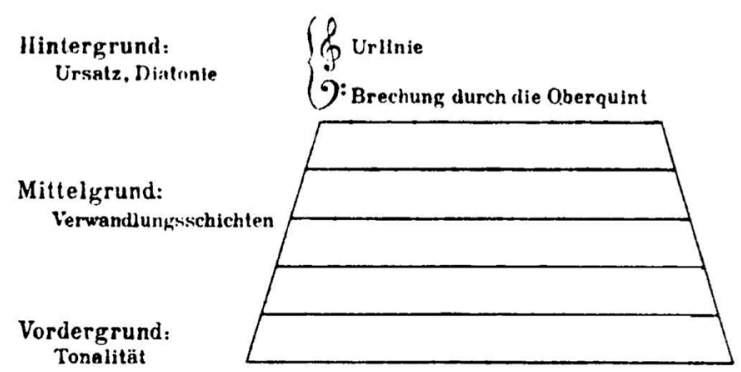

Şekil 6: Temel yapı ve katmanların prototipi (Brown, 2005, s. 69) 
İki parçadan oluşan temel yapı "uzatma" (Prolongation) yöntemiyle detaylandırılır. Schenker her üç katmanın analizinde tonal kontrpuan ilkelerini kullanır ve tanımlar. Armoniler ise melodik öğeler kullanılarak uzatılır. Bir eser analiz edilirken, bu katmanların birbiriyle olan etkileşimi, Schenker'in müzikal yapı anlayışının ana tezidir.

Babbitt, Schenker'in analizinde dört önemli kavram olduğunu söylemiştir:

- Temel yap1 ve temel çizgi

- Katmanlar

- Uzatma dinamizmi

- Armonik derecelendirmenin önemi (Babbitt, 1952, s. 261).

\section{Armonik Yapı}

18. yüzyılın ilk yarısında Rameau'nun armoniye olan katkıları, bugünkü homofonik armoni kurallarının temelini oluşturur (Lester, 1992, s. 105). Schenker' in armoni anlayışının temeli Rameau'ya dayanır. Schenker'in sistemine göre bas arpeji, temel yapının bir parçası olarak öncelikle I-V-I fonksiyonları ile gösterilir. Temel armonik bağlantılar, I-III-V-I veya I-II-V-I gibi kalıpları da içerebilir.

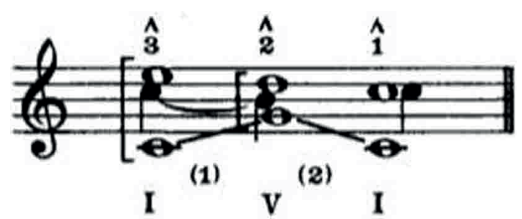

Şekil 7: Bas arpeji (Schenker,1979, Şekil 9)

Her bir sesi toniğe olan konumuna göre derecelendirmeye armonik derecelendirme (Stufen) denir. Armonik derecelendirme, tona göre önemli olan armonileri geçici olanlardan ayırt etmek için bir araçtır. Armonik derecelendirmeler romen rakamlarıyla gösterilir. Schenker Harmonielehre' de (1906), oluşturduğu akor ve derece sistemini anlatmıştır. İlk önce beşliler çemberini ve majör akoru kullanarak, majör ve minör dizilerin tüm derecelerinde art arda diyatonik akor oluşturmanın mümkün olduğunu göstermiştir.

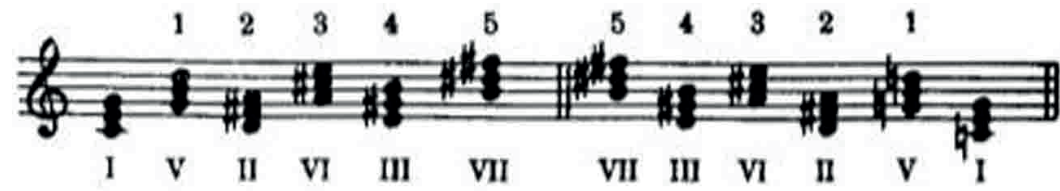

Şekil 8: Beşliler çemberi (Schenker, Harmony 1954, s. 37) 
"Karışım” (Mischung) prensibini kullanarak majör dizinin derecelerini minör dizi ile birleştirmiş, "karışım" ve "tonikleştirme" (tonicization) kavramları ile birlikte yedi derecenin tamamında tüm diyatonik akorları kapsayan tek bir majör-minör sistemi üretmiştir.

Schenker'in karışım kavramı, dizideki akor çeşitliliğini artırmak için majör veya minör dizilerden ödünç alınmış akorları ifade eder. Harmonielehre' de, majör ve minör dizideki akorların karışım yöntemiyle nasıl bir araya getirildiği anlatılmıştır. Şekil 9, tüm bu süreci özetlemektedir: Birinci satır tonik akorunu, ikinci ve üçüncü satırlar majör ve minör akorları, dördüncü satır birleştirilmiş diyatonik akorları ve beşinci satır da tüm majör ve minör akorları gösterir.

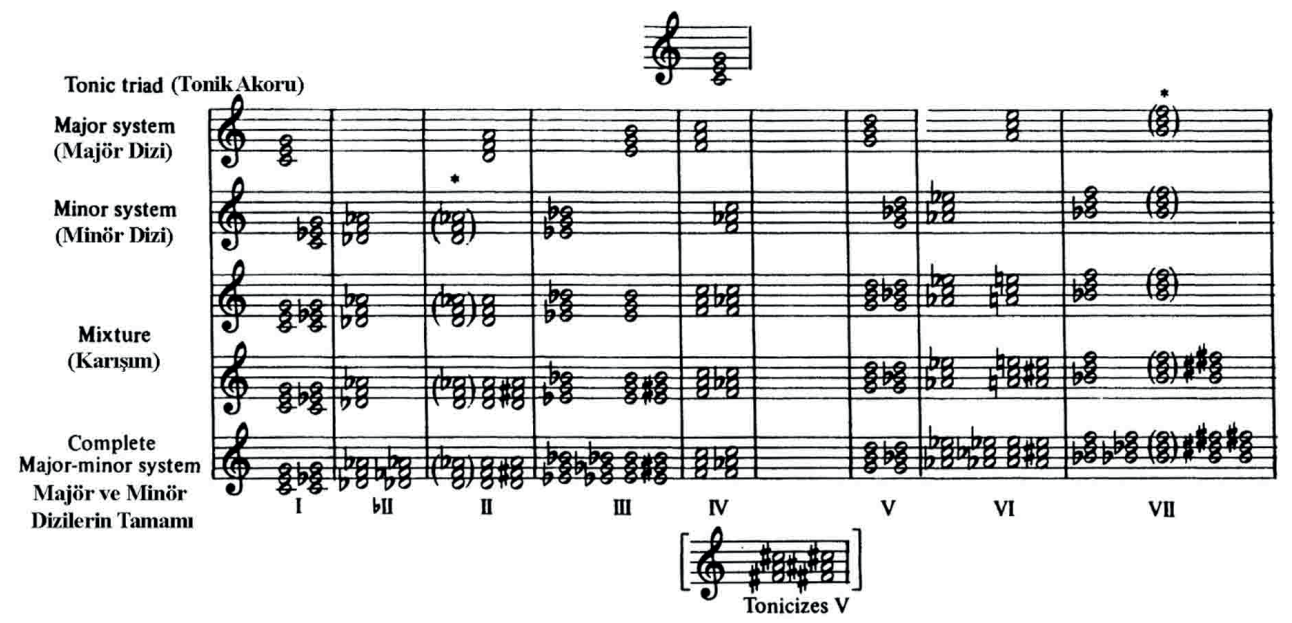

Şekil 9: Schenker akor sistemi (Brown, 1986, s. 11)

"Karışım" dizi derecelerinin diyez veya bemol alarak yarım ton incelmesi veya kalınlaşması ile oluşur. Genellikle orta planda daha sık görülür. Modun majörden minöre tekrar tekrar değiştirilmesi en çok kullanılan şeklidir. Schenker, çoğu zaman majör ve minör tonik akoru arasındaki değişimi ifade etmek için bu terimi kullanır. Salzer "karışım" prensibini sadece majör ve minör sistemler arasındaki akor değişimi (Örneğin fa majör içindeki lab majör akoru) değil, aynı zamanda majör ve minör akor tiplerinin genel değişimi olarak da ifade etmiştir. Do majörde mi majör akoru veya fa majörde lab minör akoru kullanılması buna örnektir (Salzer, 1952, s. 178-181).

Müzikte tonikleştirme, tonik dışındaki bir sesin eser içinde geçici olarak tonik olması durumudur. Schenker analizinde bir modülasyon terimidir. Modülasyon, tonik olarak yeni bir sesin duyulduğu ton merkezi değişikliğine denir. Schenker analizi tekdüzedir ve 
modülasyon kavramı bu analizde, geçici bir ton değişikliği hareketi olarak nitelendirilir. Klasik modülasyon fikrini reddetmenin yanı sıra, bu analiz aynı zamanda "ilgili" majör ve minör gibi geleneksel tonalite kavramlarını da ortadan kaldırmıştır. John Rothgep bu konuda şöyle bir açıklama yapmıştır:

"İlgili majör ve ilgili minör kavramları gerçekten de Schenker düşüncesine yabancıdır. Örneğin do majör bir eserde bir la minör akor tonikleştirilirse, Schenker daha geniş bir içeriğe bağlı olarak onu birkaç yoldan biriyle açıklar: La bası inici veya çıkıcı bir lineer bağlantıda geçit notası olabilir, $V$. dereceye işleme notası olabilir veya başka birkaç olastlıktan herhangi biri olabilir. Asla bağımsız bir ilgili ton kavramı olarak dile getirmez" (Brown, 1986, s. 15).

Temel yapı, tonik akorunun diyatonik açılımı olarak tanım gereği modülasyon içeremez. Schenker analizlerinde, herhangi bir tonal müzik parçasının yapısı diyatoniktir ve tüm modülasyonlar, diyatonik armonik derecelerin "uzaması" olarak kabul edilir.

Kavramsal açıdan Schenker, "karışım”, "tonikleştirme” ve beşliler çemberi yoluyla elde ettiği majör akorları ile üretken bir sistem oluşturmuştur. Tonik akorunun armonik prensiplerini kullanarak diğer tüm akorları etkili bir şekilde oluşturabilmesi gerçeği, sistemin aynı zamanda dönüşümsel olduğu anlamına da gelir. Tüm müzikal unsurlar melodi, armonik yapı ve lineer bağlantılar, Schenker analizinin bütünlügüunü sağlar. Armoni ve kontrapuntal boyutlar tüm yönleri ile birlikte incelenir. Harmonielehre'nin başlangıcında Schenker, analizinde bütünlügün önemini ve tüm bu unsurların dinamik olarak birbiriyle ilişkilerini bu anlamda vurgulamıştır.

\section{Melodik Kavramlar}

Armoni ve kontrpuanı birleştiren Schenker analizi, J. Fux'un (1660-1741) kontrpuan türlerini melodik hareketlerin kullanımında temel almıştır. Her akoru tek tek derecelendirmek yerine, derecelerin genişlemesinin daha önemli olduğunu düşünen Schenker, uzun süreli armonik dereceler üzerinde değişen akorları kurgulamış ve bu bağlamda analizde en çok iki temel kavram üzerinde durmuştur: "uzatma tekniği” ve "dışa besteleme (Auskomponierung)'”. Uzatma tekniği kompozisyon kurallarına tabiidir. Forte ve Gilbert uzatma tekniği için şu tanımı yapmışlardır: Uzatma bir nota (melodik uzatma) veya bir akor gibi (armonik uzatma) müzikal öğelerin her zaman tam anlamılla sunulmadan etkisini sürdürmesidir (Forte ve Gilbert, 1982, s. 142). 
Schenker'in uzatma tekniği ile her katman birbirinin içeriğini uzatır. Yani sonraki her plan önceki planın içeriğini genişletir veya uzatır. Joseph N. Straus uzatma için dört koşulun gerekli olduğunu öne sürmüştür. Bunlar özetle:

- Konsonans ve dissonans bulunmas1

- Dizi dereceleri hiyerarşisi

- Notaların yapısal ağırlığına göre süsleme

- Armoni ve voice leading koşulları (Straus, 1987).

Uzatma tekniğini daha çok "orta plan"da kullanan Schenker için bu teknik, analizin temelinde yer alır ve en önemli koşullarından biridir.

Katz uzatmanın birkaç yolla yapılabileceğini anlatmıştır:

- Dissonant bir geçit notasını yatay hareketle konsonanta dönüştürerek, yatay hareketle yeni bir akor elde ederek,

- Bir notayı yatay hareketle oktavıyla değiştirerek,

- Seslerin yerlerini değiştirerek,

- Akoru kırarak, melodik çizgiyi akorun aralıkları vasıtasıyla uzatarak (Katz, 1935, s. 315-316).

Uzatma tekniği, Schenker analizine göre kompozisyon kurallarına tabii olarak yapılır. Armonik ve melodik olarak yapılabilen uzatma tekniği, yatay hareketlerle, geçit ve işleme akorları ve sesleriyle, akorun arpej halinde tekrarılla ve paralel hareketlerle gerçekleştirir. Uzatma tekniğinin ilk prensibi tonal boşluğu notalar ile doldurmak olduğundan, analizin temel amaçlarından biri belirli derecede yatay bir akoru birbiriyle yakından ilişkili olduğu seslerle doldurarak, notalar arasındaki lineer bağlantıları göstermektir. Lineer bağlantı (Zug), bazı konsonant aralıkların yanaşık olarak doldurulmasıdır. Örneğin, temel çizgi bir lineer bağlantıdır. Çünkü tonik akorunun iki notasını birleştirmiştir. Genellikle grafik notasyonda bağlantının ilk notasından son notasına kadar bir bağ ile altı çizilir. Dışa besteleme ise lineer bağlantı kavramı içinde yer almaktadır ve bir akor olarak temsil edilen, yapısal olarak anlamlı bir armoninin, eserin diğer pasajlarına ardışık olarak yeniden yazma yoluyla "açılabileceği” kavramına dayanır.

Schenker (1979), "dışa besteleme lineer bağlantının ikinci bir taklitidir demiştir” (s.74). Voice leading kuralları ile akorun açılması ve uzaması için analizlerde kullanılır. Müzikte voice leading yatay olarak seslerden "çizgiler" oluşturmak için sesleri ilerletmek yo- 
luyla yapılır. Melodik akıcılık ve yanaşık hareket voice leading için ana kuraldır. Temel kontrpuanın ilkelerini analiz üzerinde kullanarak melodik uzatma tekniğini uygular. Şekil 10'da voice leading hareket tiplerini görmektesiniz:

parallel motion

(paralel hareket)

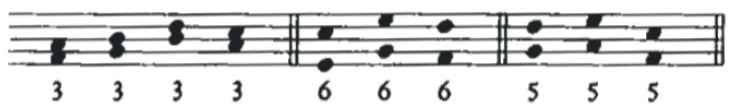

oblique motion

(eğik hareket)

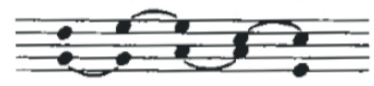

similar motion

(benzer hareket)

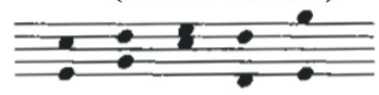

contrary motion

(ters hareket)

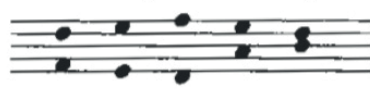

Şekil 10: Voice Leading hareket tipleri (Aldwell ve Schachter, 2003, s. 71)

Schenker analizindeki melodik kavramlara diğer bir örnek de "açılma"dır (Ausfaltung). Açılma arka plan katmanında aynı armoniye ait iki notayı gösterir. "Polifonik melodilerde iki veya daha fazla ses, kademeli hareket, atlama veya her ikisinin kombinasyonu ile ilişkili olabilir. İki ses arasında farklı bir hareket türü açılma olarak adlandırılır. Genellikle bir çift aralığı doğrusallaştıran bu teknik zengin kompozisyon olanakları sunar (Cadwallader ve Gagne,1998, s. 131).

Açılma, melodik ve armonik olarak iki şekilde yapılabilir. Melodik açılma, çapraz nota saplarıyla gösterilir. Açılmalar, armonileri uzatan hareketler olarak kullanılırlar.

Açılma, Şekil 11'de çapraz sekizlik notalarla gösterilmiştir:

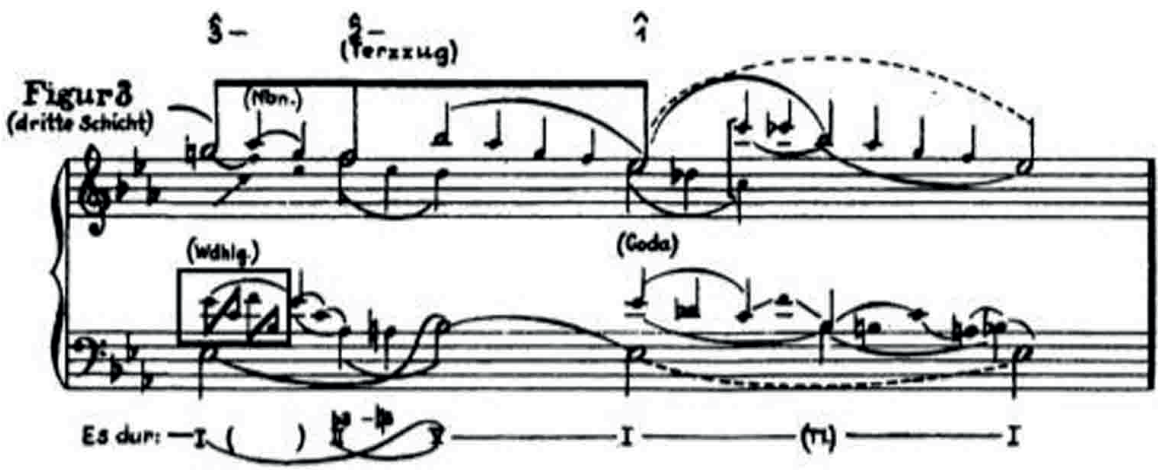

Şekil 11: Schenker'in ilk açılma sembolü, Das Meisterwerk in der Musik 3 (Garrison, 2012-2013, s. 115) 
Schenker analizinde kullanılan melodik hareketlerin hepsi aslında uzatma tekniğinin içinde değerlendirilebilir. Tonaliteyi değiştirmeden tonik dışındaki tüm seslerin dizinin armonik dereceleri olduğunu kabul eden Schenker, fonksiyon ilişkilerini daha geniş bir bakış açısı ile görmüş, uzun fonksiyon ilişskilerini uzatma tekniği ile analiz etmiştir.

\section{Grafik Notasyon}

Grafik notasyon, Schenker analizinin önemli bir bölümünü oluşturur. Schenker grafikleri, "hiyerarşik" bir notasyona sahiptir. Nota değerleri, yapısal önem derecelerini ayırt etmek için kullanılır. Schenker grafikleri ritmik değerleri göstermezler. Temel çizgi ve bas arpejine ait notalar içi boş ve kalın bir nota sapı ile yazılır. Schenker notasyonunda içi boş notalar, hiyerarşik üstünlüğe sahiptir. Saplı ve içi doldurulmuş notalar, ikincil önemi olan notaları gösterir. Sapı olmayan içi dolu notalar ise üçüncül öneme sahip notalardır. Schenker notasyonunda nota sapları kesilebilir.

Şekil 12'de sol bemolün bas arpejine, si bemolün ise temel çizgiye ait olan temel sesler olduğu görülmektedir. Temel çizgi 3'ten 1'e doğru iniş yapmaktadır.

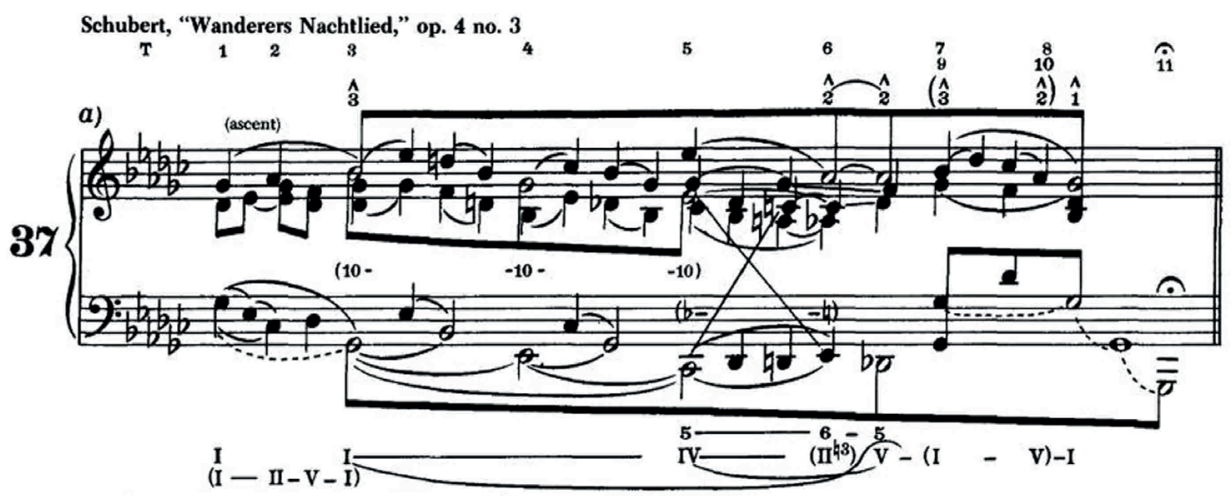

Şekil 12: Schenker Notasyonu (Schenker, 1979, Şekil 37a)

Romen rakamları armonik dereceleri, üzeri şapkalı rakamlar tonun melodik derecelerini, şapkasız rakamlar ise ölçü numarası ve bas şifrelerini ifade eder. Bağlar, voice leading hareketini gösterir. Noktalı çizgi bağ ise aynı nota aralığını gösterir. Kuyruklu sekizlik notalar, yapısal açıdan önemli bir işleme notasını gösterir. 


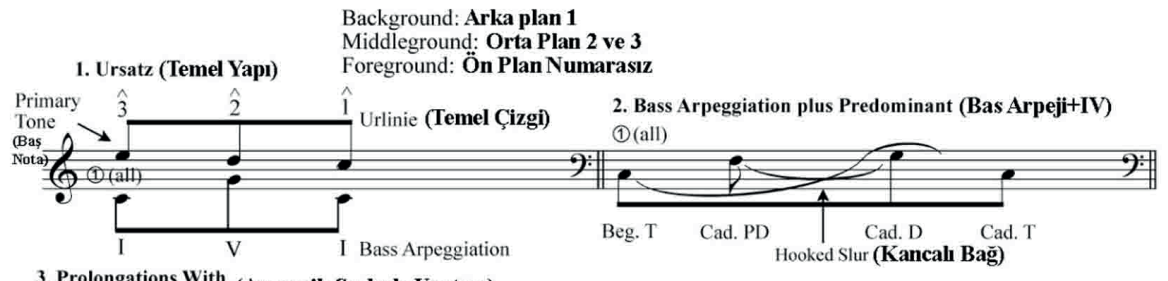

3. Prolongations With (Armonik Seslerle Uzatma)
Only Harmonic Tones
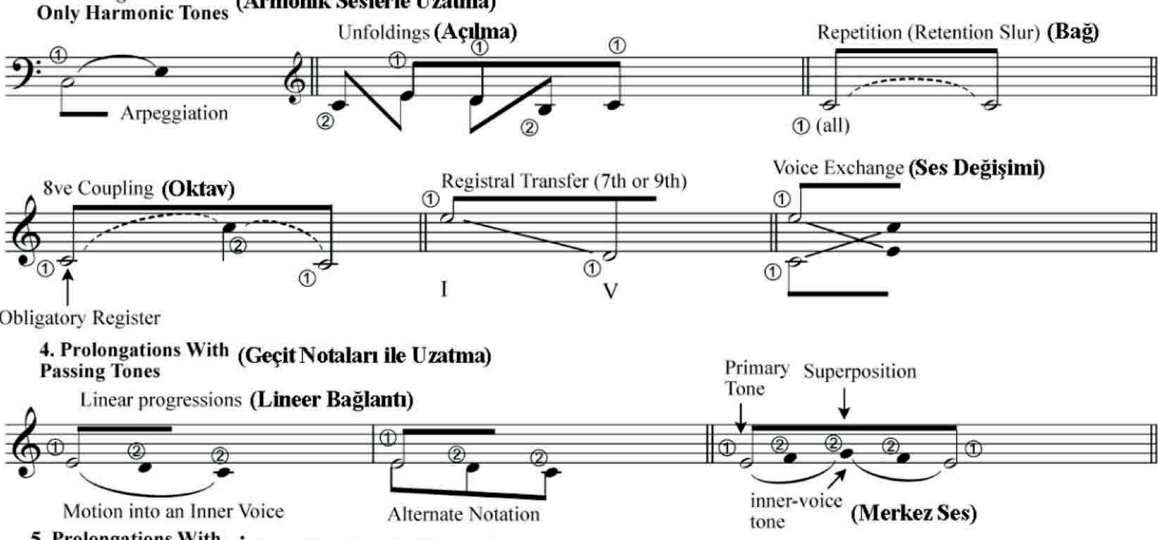

5. Prolongations With (İşleme Notaları ile Uzatma)
Neighbor Tones

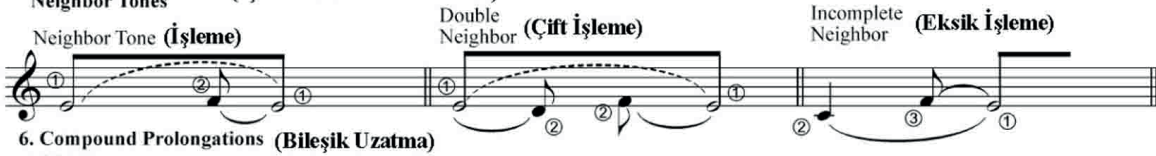

6. Compound Prolongations (Bileşik Uzatma)

Initial Ascent

Anstieg
Motion From an Inner Voice Arpeggiated

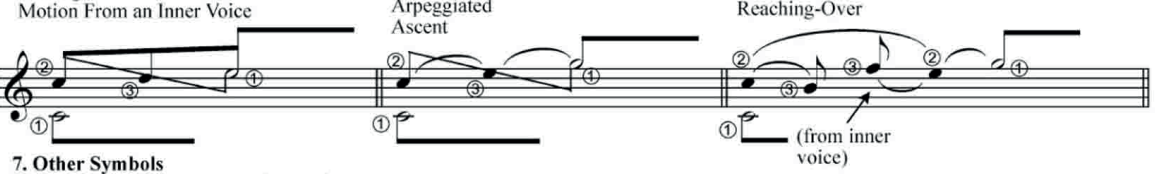

7. Other Symbols

Interruption (Equal Two-Branch Notation)

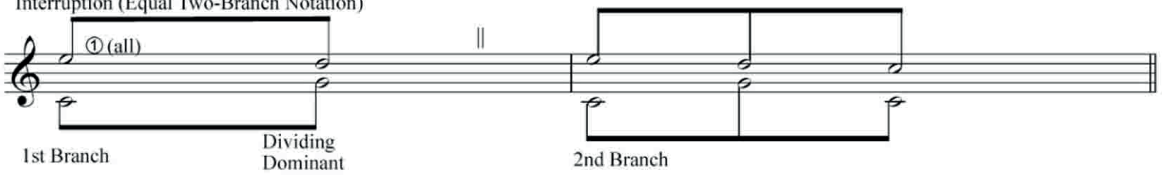

Substitution (Implied Tone) (İkame Ses)

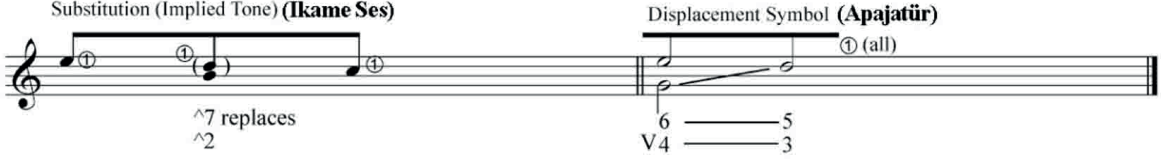

Şekil 13: Schenker grafik sembolleri (Wadsworth, 2016, s. 205)

Schenker'in grafik olarak ifade ettiği bütün planlar, ön plan hariç, grafik üzerinde birbirine paralel ve yatay olarak gösterilir. Kolaylıkla eş zamanlı takip edilebilir, birbirleriyle kıyaslanabilir, dikey olarak ilişkilendirilebilirler. 


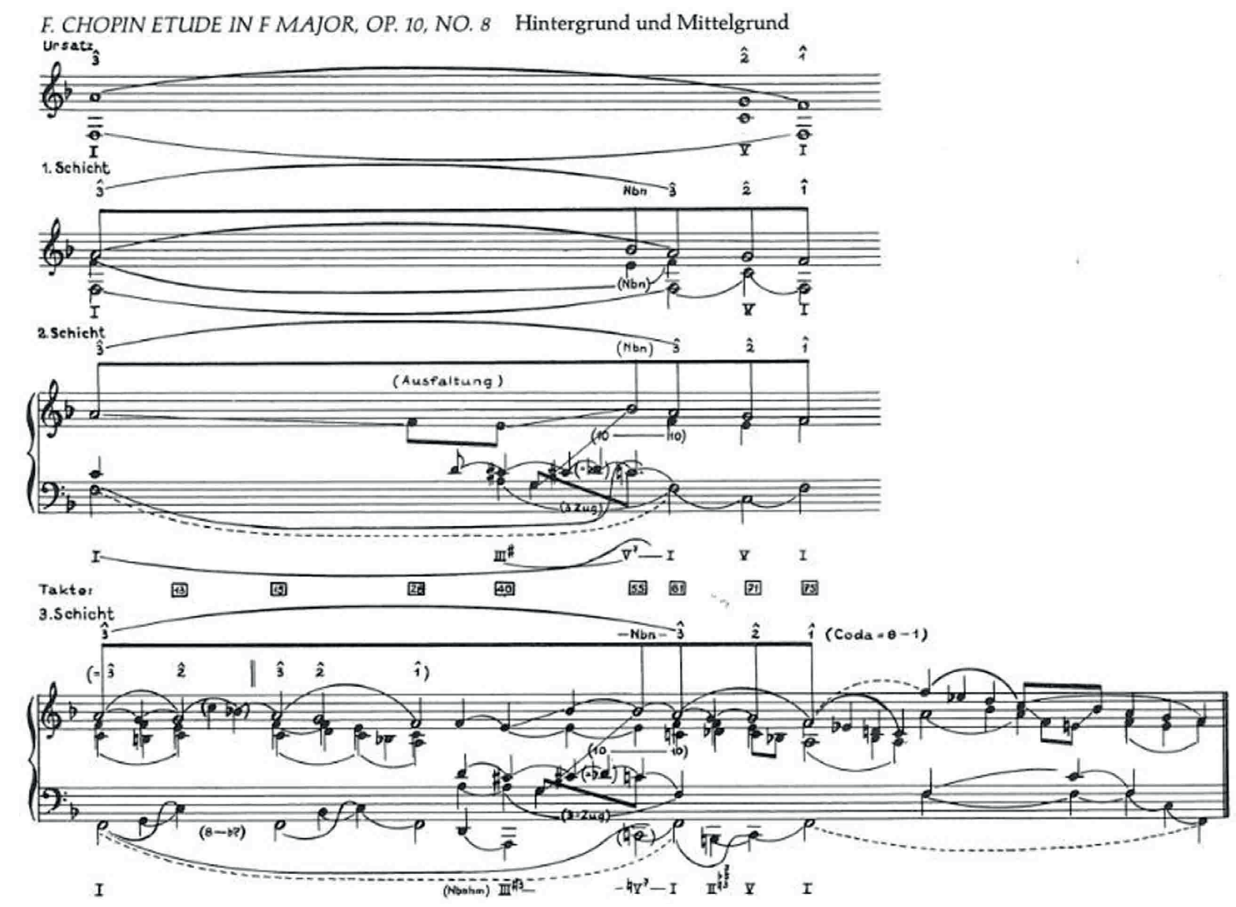

Şekil 14: Schenker analizinde orta plan ve arka plan grafiği (Schenker, 1969, s. 37)

Schenker analizi, eser içindeki süsleme katmanlarını atarak analiz yaparken eseri sadeleştirme üzerine kurulmuştur. Notasyon üzerinde "azaltım” (reduction), müziğin temel yapısını ortaya çıkarır. Schenker'in kuramını oluşturmada bu düşünce şekli önemli bir yer tutar. Schenker analizinde kullanılan azaltım tekniğinin kökeni Rönesans'a kadar uzanır.

Şekil 15'te, 16. yüzyılın ilk yarısında yaşamış besteci ve organist Hans Buchner'in (1483-1538) üç sesli koralindeki ritmik azaltma örneği görülmektedir:
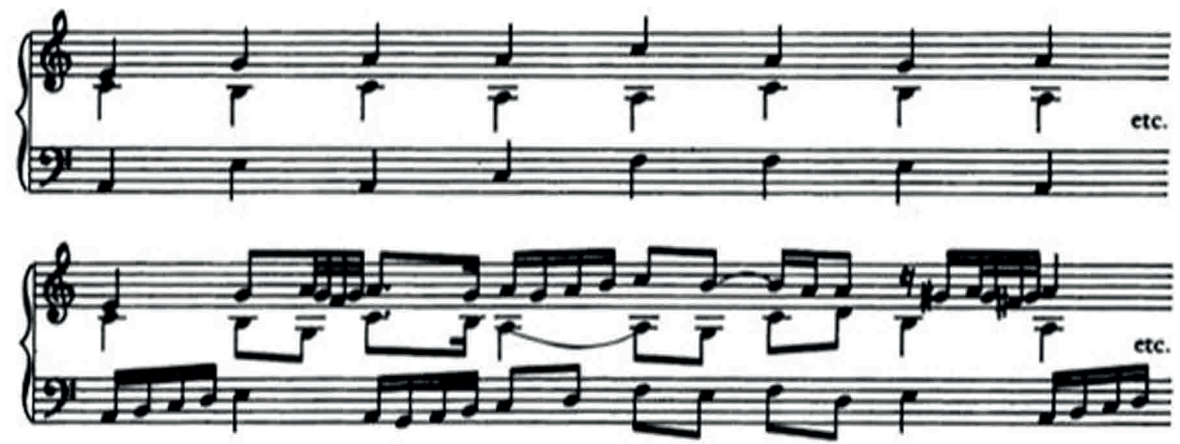

Şekil 15: Hans Buchner, Üç Sesli Koral (Morgan, 1978, s. 77) 
Arnold Schering (1877-1941) 14. yüzy1l madrigallerini incelemiş ve disembellishing tekniği ile süslemeleri ayıklayarak parçaların melodik yapılarını sadeleştirmiş, birbirinden farklı görünen birçok madrigalin aslında aynı melodik yapıya sahip olduğunu görmüştür (Sadie, 2001, s. 544). Schering'in bu yaklaşımı, Schenker'in çalışmalarına da bir nevi ön hazırlık yapmıştır.

Forte bu konuda tarihsel bir fenomen olarak görülen azaltım tekniğinin özellikle Schenker bakış açısı içinde bir miktar dikkate alındığını söylemiştir (Forte, 1961, s. 16-17).
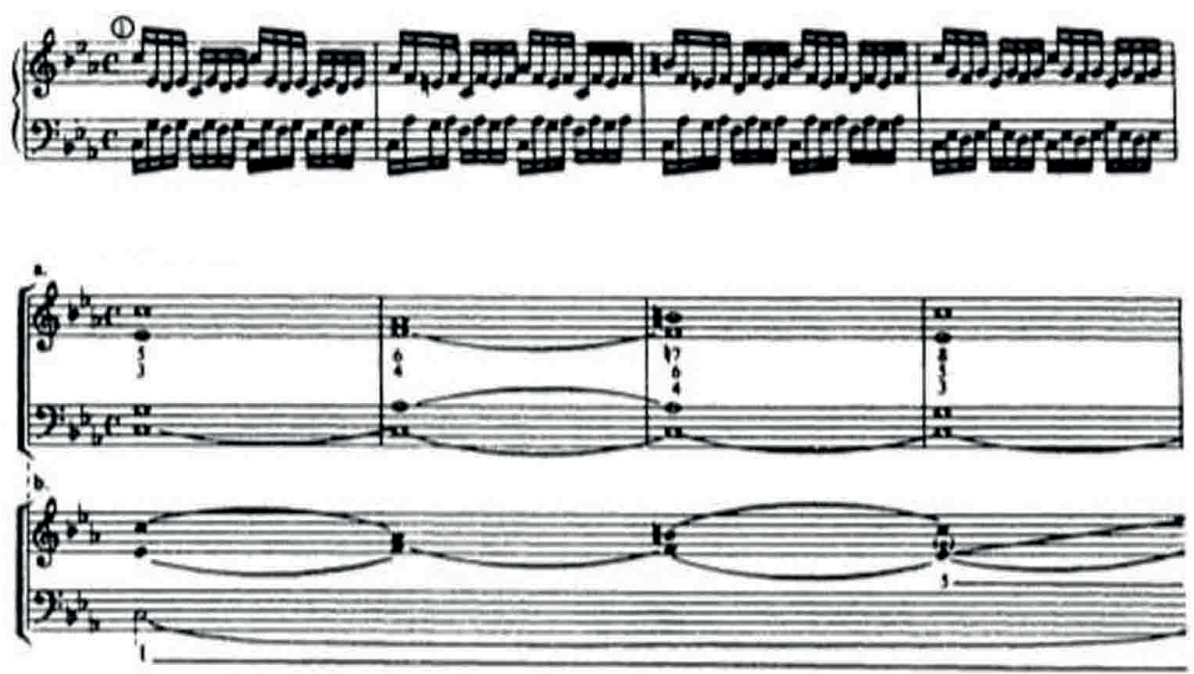

Şekil 16: Bach Prelüd No. 2 Do Minör, 1-4. ölçüler (Agawu, 1989, s. 288)

\section{Analiz Örnekleri}

Schenker'in analiz yöntemi, eseri daha basit temellere indirgeyen minimal bir sistemdir. Analizi daha çok I-V-I üzerine kurgulayan Schenker'in analizine göre Şekil 17'de Bach Do Minör Prelüd'ün ilk dört ölçüsünün armonik yapısı görülmektedir. A şıkkında eserin orijinal hali, B şıkkında klasik analiz yöntemine göre analiz edilmiş hali, $\mathrm{C}$ şıkkında ise Schenker tarzında analiz edilmiş hali görülmektedir. Schenker analizi örneğinde ilk dört ölçünün I. derece fonksiyonunda kaldığı görülmektedir. 
a)
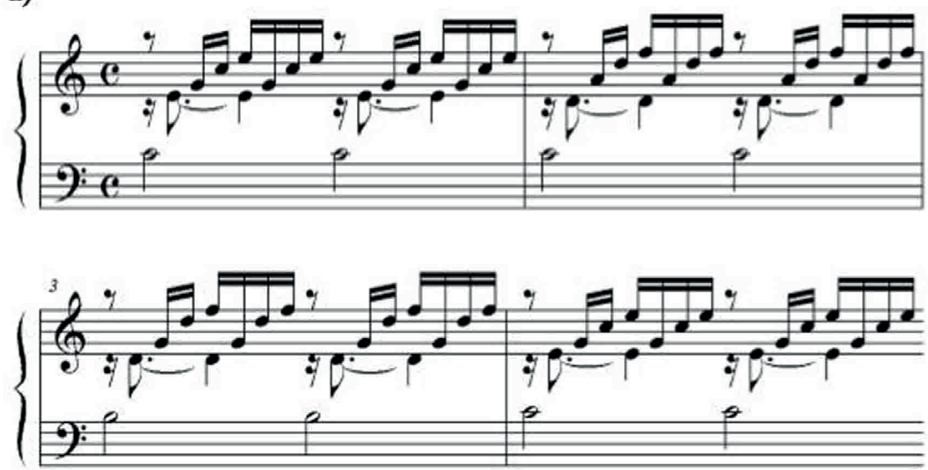

b)

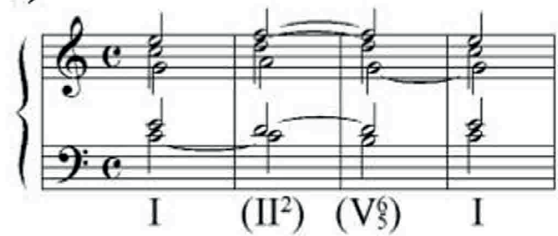

c)

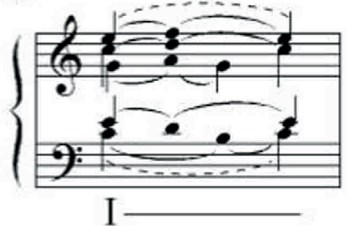

Şekil 17: Do Majör Prelüd, 1-4 ölçüler (Meeùs, 2011-2012, s. 12)

Aynı prelüdün ilk 19 ölçüsünün Schenker analizi Şekil 18'de görülmektedir:
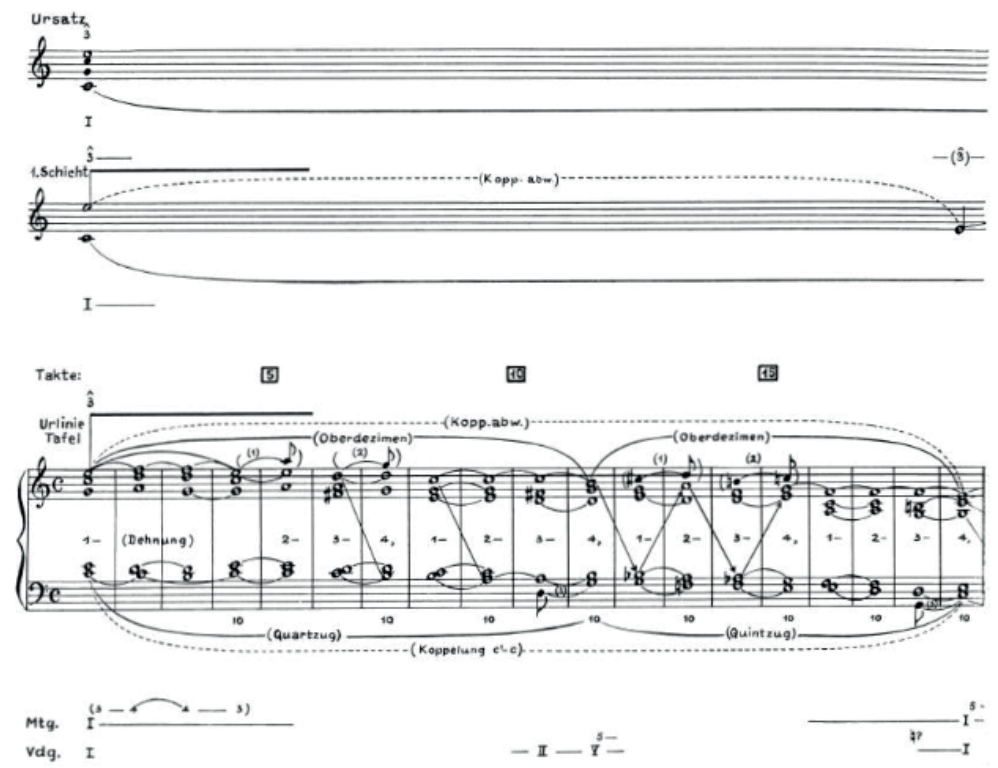

Şekil 18: Do Majör Prelüd'ün Schenker analizi, 1-19. ölçüler (Schenker, 1969, s. 30) 
Beethoven Sonat Op. 26'nın armonik analizi Şekil 19'da görülmektedir. Eser üç kesitli formda yazılmıştır. İlk otuz ölçüsü "A" kesitidir. Armonik analiz de sadece "A" kesitine yapılmıştır. "B" kesiti la bemol majör olarak başlamaktadır.

Grafik notasyonda cümle tekrarları tekrar edilmemiştir. Her sekiz ölçünün sonu yarım kadans olarak kabul edilmiştir. Uzatmalar için noktalı bağlar kullanılmıştır. Önemli fonksiyonlar içi boş notalarla gösterilmiştir.

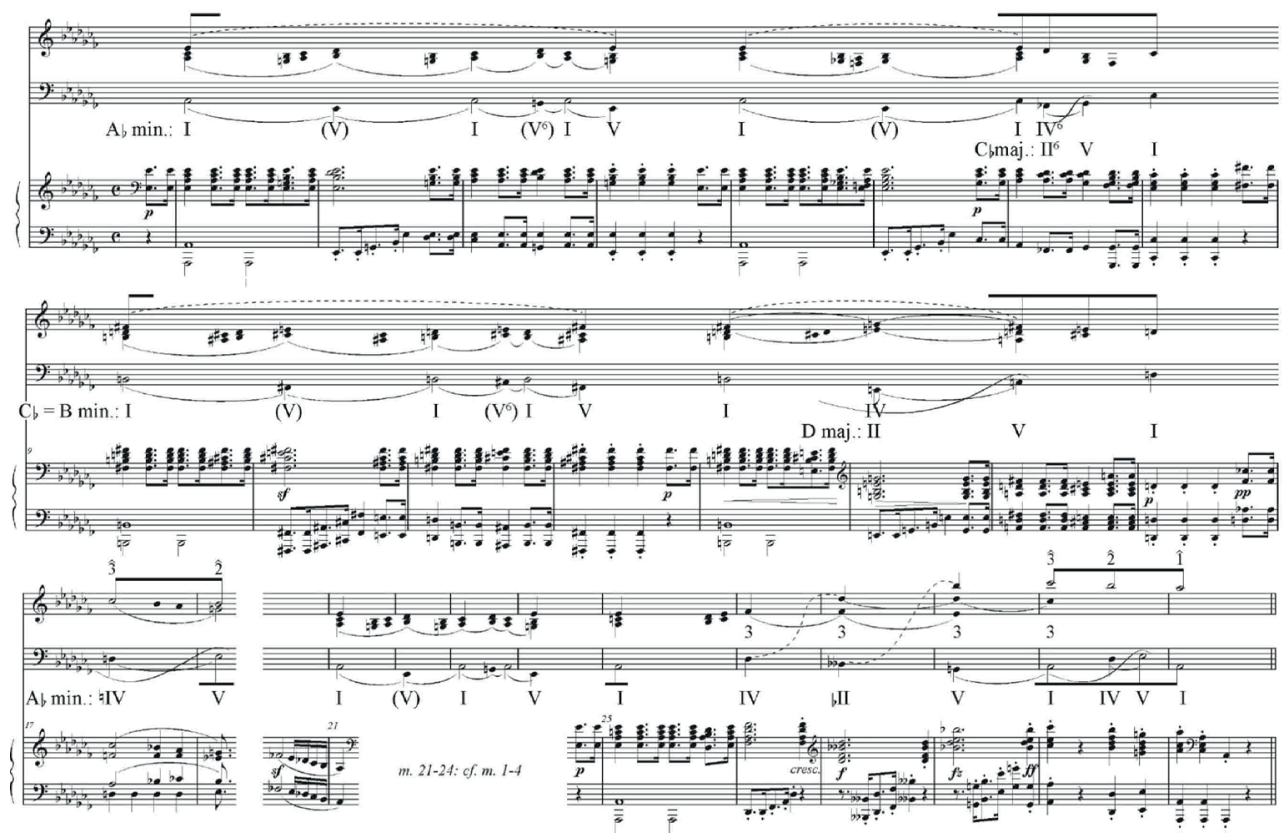

Şekil 19: Beethoven Sonat Op. 26 3. Bölüm, Schenker analizi ve armonik analiz, 1-30. ölçüler

(Beduschi ve Meeús, 2010, s. 168)

Aynı sonatın tüm bölümünün analizini yapan Schenker'in örneğinde modülasyonun azlığı oldukça dikkat çekicidir. Trio'daki la bemol majör tonuna geçişi de karışım olarak değerlendirmiştir. 17. ölçüye kadar I. derece fonksiyonunda kalmıştır. Bas arpeji la bemol ile başlamış, baş ses (Kopfton) do bemol ile başlayarak temel çizgi 3-1 inişini gerçekleştirmiştir. 


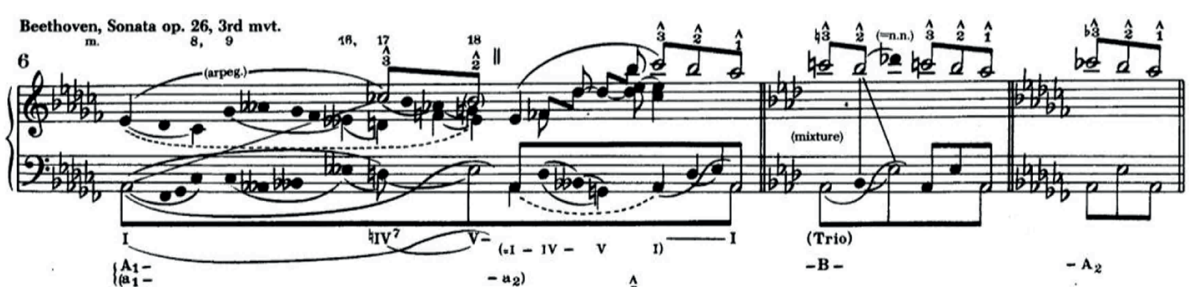

Şekil 20: Beethoven Sonat Op. 26, 3. Bölüm, Schenker analizi (Schenker, 1979, Şekil 40-6)

Beethoven Piyano Sonatı No.21'de, bas çizgisindeki kromatik iniş göze çarpmaktadır. İlk dört ölçü yarım kadansla bitmiştir. İkinci dört ölçü ise ilk dört ölçünün alt dominantında bir tekrarıdır ancak fa minörde bitmiştir. Sonrasında do minör devam etmiş, 13. ölçünün sonunda ise dominantında kalmıştır.

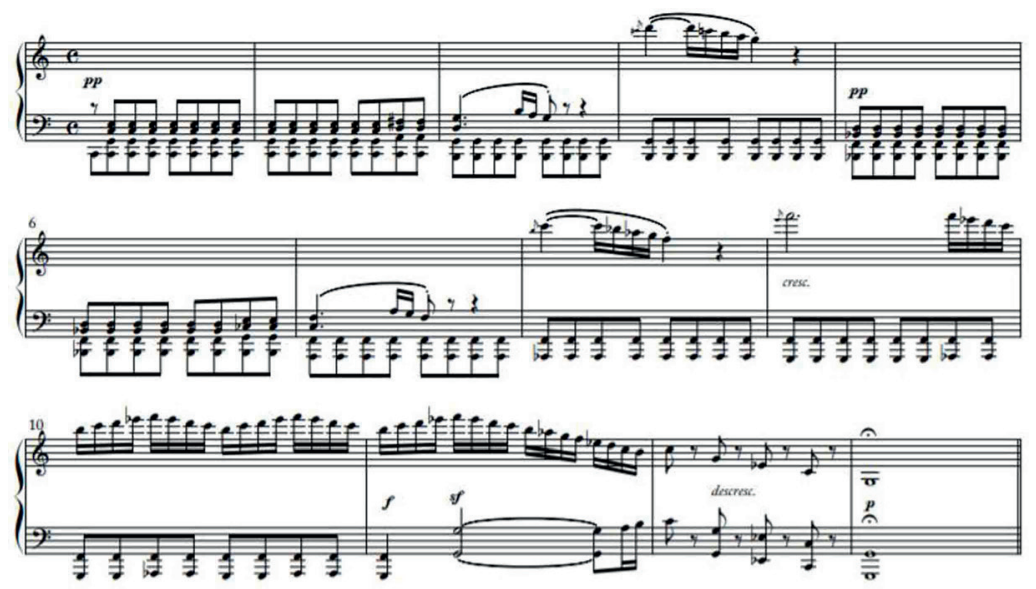

Şekil 21: Beethoven Piyano Sonatı No. 21 Do Majör "Waldstein”, 1-13. ölçüler (Temperley, 2011, s. 165)

Schenker analizine göre ilk sekiz ölçü I. derece fonksiyonundadır. Diğer beş ölçü ise V. derece fonksiyonundadır. Partisyon üzerinde azaltma tekniği uygulanmıştır. Baş ses 5 'liden başlamaktadır. Kromatik inen notalar geçit notaları olarak kabul edilmiştir.

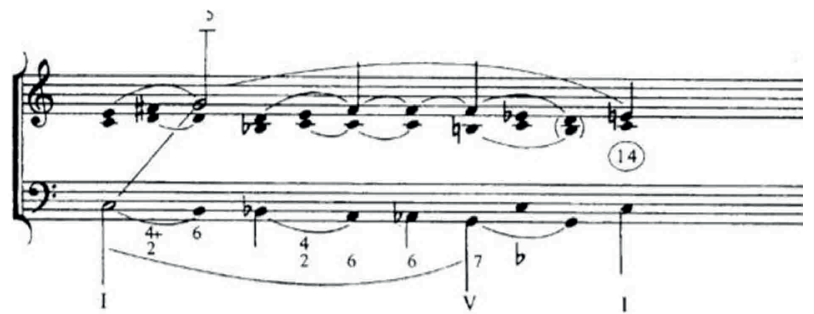

Şekil 22: Beethoven Piyano Sonatı No. 21 Do Majör "Waldstein”, 1-13. ölçüler, Schenker analizi (Temperley, 2011, s. 165) 


\section{Sonuç}

Geleneksel kuramcılar, müzik tarzlarının çeşitli dönemlere göre farklılık gösterdiğini savunurken Schenker, tüm büyük bestecilerin müziğindeki yaratıda temel ilkelerin aynı olduğunu ve analizin temelinin tonik akoruna dayandığını anlatır. Müzik analizi için Schenker analizinin prensiplerini anlamak, kendine has terminolojisini kullanarak eser analiz edebilmek, analiz adına yeni bir bakış açısı kazandıracaktır. Ancak Schenker analizi her ne kadar tonal bir analiz yöntemi de olsa kavramların anlaşılması ve uygulanmas1 çok kolay olmayabilir. Özellikle başlangıç seviyesinde öğrenciler için zor ve anlaşılmas1 güç bir yöntem olduğu düşünülebilir. Az uygulanan bir yöntem olması da diğer bir etkendir. Tüm analiz yöntemlerini tanımak ve tanıtmak, müziği incelemede yeni yöntemler keşfetmek kendini geliştirme açısından oldukça yararlı olacaktır.

Schenker analizinin, üç temel katmanın her analizde tespit edildiği tutarlı bir yaklaşım olduğu, eser analiz ederken, bir miktar esnekliğe izin veren titizlikle hazırlanmış bir analiz metodolojisi olduğunu söylemek mümkündür. Geleneksel analiz yöntemleri ile analiz edilmiş bir eser Schenker analizi ile analiz edildiğinde farklı sonuçlar alındığı da görülmektedir. Bu farklılık sadece Schenker analizine özgü değildir. Çeşitli analiz yöntemleri ile aynı eserin farklı yönleriyle ilgili farklı görüşlere sahip olunabilir. Bu bağlamda göz ardı edilmemesi gereken en önemli nokta, hiçbir analiz yöntemi veya yaklaşımının bir diğerinden daha üstün ve ayrıcalıklı olmadığıdır.

Finansal Destek: Yazar bu çalışma için finansal destek almamıştır.

\section{Kaynakça}

Aldwell E. ve Schachter C. (2003). Harmony\&voice leading. United States: Thomson/Schirmer

Babbitt, M. (1952). Review of "Structural hearing: tonal coherence in music" by Felix Salzer. Journal of the American Musicological Society(3), 260-265.

Beach, D. (1969). A Schenker bibliography. Journal of Music Theory, 2-37. https://www.jstor.org/stable/843213 adresinden alınd 1

Beduschi, L. ve Meeús, N. (2010). Schenkerian analysis at the Sorbonne. Music Theory Pedagogy Online (24), 159173. Music Theory Pedagogy Online. adresinden alındı

Brown, M. (1986). The diatonic and the chromatic in Schenker's "Theory of harmonic relations". Journal of Music Theory, 1-33. https://www.jstor.org/stable/843407 adresinden alınd1

Brown, M. (2005). Explaining tonality schenkerian theory and beyond. New York: University of Rochester Press.

Cadwallader, A. ve Gagne, D. (1998). Analysis of tonal music: A schenkerian approach. New York: Oxford University Press. 
Cook, N. (1987). A guide to musical analysis . New York: Oxford University Press.

Dallin, L. (1964). Techniques of twentieth century composition. Iowa: WM.C. Brown Company Publishers.

Drabkin, W. (2002). Heinrich Schenker. (T. Christensen, Dü.) The Cambridge History of Western Music Theory, 812-843.

Edward, A. ve Schachter, C. (2003). Harmony and voice leading. Belmont,Ca: Wadsworth.

Forte, A. (1959). Schenker's conception of musical structure. Journal of Music Theory, 3(1), 1-30. https://www.jstor. org/stable/842996 adresinden alınd1

Forte, A. (1962). The compositional matrix. New York.

Forte, A. (1985). Pitch-class set analysis today. Music Analysis, 29-58. https://www.jstor.org/stable/854234 adresinden alınd 1

Forte, A. ve Gilbert, S. E. (1982). Introduction to schenkerian analysis. New York: Norton

Garrison, R. (2012-2013). Unrolling Schenker's ideas of musical "Unfolding”. Theory and Practice, 111-138. https://www.jstor.org/stable/43864908 adresinden alınd1

Hansen, N. C. (2010). The legacy of Lerdahl and Jackendoff's 'A Generative Theory of Tonal Music': Bridging a significant event in the history of music theory and recent developments in cognitive music research. Danish Yearbook og musicology, 33-55.

Katz, A. T. (1935). Heinrich Schenker's method of analysis. The Musical Quarterly, 21(3), 311-329. https://www. jstor.org/stable/41035686 adresinden alınd1

Larson, S. (1997). The problem of prolongation in "Tonal" music: Terminology, perception, and expressive meaning. Journal of Music Theory, 101-136. https://www.jstor.org/stable/843763 adresinden alınd

Lerdahl, F. ve Jackendoff, R. (1983). A generative theory of tonal music. Massachusetts: MIT Pres. https://www. researchgate.net/publication/268189854 adresinden alınd

Morgan, R. P. (1978). Schenker and the theoretical tradition: The concept of musical reduction. College Music Symposium, 18(1), 72-96. https://www.jstor.org/stable/40373919 adresinden alınd1

Morris, R. D. (1998). Voice-leading spaces. Music Theory Spectrum, 20(2), 175-208. https://www.jstor.org/stable/746047 adresinden alınd 1

Sadie, S. (Dü.). (2001). The new grove dictionary of music and musicians (2 b., Cilt 1). New York: Oxford University Press.

Sadie, S. (Dü.). (2001). The new grove dictionary of music and musicians (2 b., Cilt 25). New York: Oxford University Press.

Salzer, F. (1952). Structural hearing: Tonal coherence in music Volume I. New York: Charles Boni.

Say, A. (2002). Müzik sözlüğ̈̈. Ankara, Müzik Ansiklopedisi Yayınları

Schenker, H. (1954). Harmony. (O. Jonas, Dü., \& E. M. Borgeses, Çev.) Chicago, London: The University of Chicago Press.

Schenker, H. (1969). Five graphic music analysis. New York: Dover.

Schenker, H. (1979). Free composition lı of musical theories and fantasies. (E. Oster, Çev.) New York: New York, London, Longman.

Straus, J. N. (1987). The problem of prolongation in post-tonal music. Journal of Music Theory, 31(1), 1-21. https:// www.jstor.org/stable/843544 adresinden alındı

Temperley, D. (2011). Composition, perception, and schenkerian theory. Music Theory Spectrum, 33(2), 146-168. doi:10.1525/mts.2011.33.2.146

Wadsworth, B. K. (2016). Schenkerian analysis for the beginner. Journal of Music Theory Pedagogy, 177-220.

Yüksel, M. (2013). Schenker analizi: Robert Schumann, “Askerin Marşı”, opus 68/2 sol majör. Akdeniz Sanat Dergisi, 3(6), 163-168. http://dergipark.gov.tr/akdenizsanat/issue/18005/189134 adresinden alındı 